\title{
Studies in Neotropical Paleobotany. XV. A Mio-Pliocene Palynoflora FROM THE EASTERN CORDILLERA, BOLIVIA: IMPLICATIONS FOR THE UPLIFT History OF The Central Andes ${ }^{1}$
}

Alan Graham ${ }^{2,4}$, Kathryn M. Gregory-Wodzicki ${ }^{3}$, and Kari L. Wright ${ }^{2}$

${ }^{2}$ Department of Biological Sciences, Kent State University, Kent, Ohio 44242 USA

${ }^{3}$ Lamont-Doherty Earth Observatory of Columbia University, Palisades, New York 10964-8000 USA 
${ }^{1}$ Manuscript received -----; revision accepted -----.

The authors thank Julio Balcázar, Shirley A. Graham, Luis Huanca, and Michael Nee for valuable field assistance; James Solomon and Michael Nee for information on the modern vegetation of Bolivia; Gary W. Barker and Gordon D. Wood (BP-AMOCO) for arranging for the processing of some of the samples; Robyn Burnham for providing copies of some older literature on Bolivian paleobotany; and Michael Nee and Shirley A. Graham for reading the manuscript. Research supported by National Geographic Society Grant 6605-99 (to AG) and National Science Foundation Grant EAR-9905164 (to KMG).

${ }^{4}$ Author for correspondence. 


\section{ABSTRACT}

An assemblage of 33 fossil pollen and spores, recovered from the $3600-\mathrm{m}$ high Pislepampa locality of E. W. Berry, Eastern Cordillera, Bolivia, adds considerably to our knowledge of three aspects of the region in late Neogene time: 1) the paleovegetation, 2) the paleoclimate, and 3) the paleoelevation of the Central Andes. The plant microfossils recognized are Isoetes, Lycopodium (three types), Cnemidaria, Cyathea (three types), Grammitis, $\underline{\text { Hymenophyllum, Pteris, }}$ trilete fern spores (two types), Danaea, monolete fern spores (four

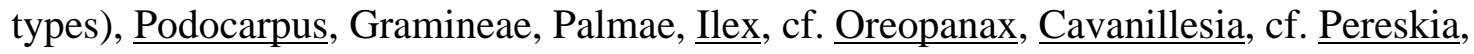
Compositae (three types), Ericaceae, Tetrorchidium, and unknowns (three types). The diversity of the Compositae suggest that this flora has a maximum age around the Miocene-Pliocene boundary, that is, 6-7 million years. All members of the paleocommunity presently grow in the bosque montano húmedo (cloud forest) along the eastern slope of the Central Andes of Bolivia, which occurs between MATs (mean annual temperatures) of $\sim 10^{\circ}$ and $20^{\circ} \mathrm{C}$. The Pislepampa flora probably represents the lower limits of this forest because the fossil leaves collected by Berry from the same locality all have entire margins, suggesting that the flora grew near the cloud forest-tropical forest transition. Presently, the lower limit of the cloud forest forest has MATs of $\sim 20^{\circ} \mathrm{C}$, a mean annual precipitation between 1000 and $1500 \mathrm{~mm}$, and that part containing most of the identified genera of fossil pollen is found at elevations around 1200-1400 m. These conditions are thus inferred for the Pislepampa flora; however, because of the uncertainty in the magnitude of global climate change and in possible changes in the ecological range of plant genera, we estimate an error of at least $\pm 1000 \mathrm{~m}$ (2 SD) for the paleoelevation estimate. When the total uplift is corrected for probable amounts of erosionally driven isostatic rebound, the paleoelevation estimate suggests that from one-third to one-half of the uplift of the 
Eastern Cordillera had occurred by the beginning of the Pliocene. This estimate is consistent with other paleoelevation estimates from the Central Andes.

Key words: Bolivia; Central Andes; Mio-Pliocene; paleoelevation; palynoflora. 
A principal factor in determining the distribution and evolution of biotas is climate, and a major component of climate is atmospheric circulation. Consequently, any event that affects atmospheric circulation becomes a significant forcing mechanism for climatic and biotic history. One such factor is the uplift of mountain ranges or continental plateaus. The three great mountain systems of the world, the Himalayas, the North American Cordillera, and the Andean Cordillera, have all been uplifted since 70 million years, and together probably make the present Earth one of the most mountainous in geologic history (Ruddiman et al., 1997).

The uplift of mountains and plateaus affects climate because it changes patterns of precipitation and seasonal heating, creates a barrier to atmospheric circulation, affects upper atmosphere flow patterns, and may increase rates of chemical weathering (Ruddiman and Kutzbach, 1989; Raymo and Ruddiman, 1992; Hay, 1996; Broccoli and Manabe, 1997). In order to understand how climatic changes affect the biota, it is important to study the elevational history of uplifted regions.

Several techniques are available for estimating the height of mountains in the geologic past (see Graham, 1999a, Chapter 2, pp. 207-210; Chase et al., 1998; Gregory-Wodzicki, 2000). These include indicators from a variety of subdisciplines including tectonics, sedimentology, geochemistry, volcanology, geomorphology, geochronology, and paleobotany. As of now, some of the most quantitative estimates are derived from paleobotanical techniques, which use the fact that plants are sensitive recorders of climate and other environmental conditions. One paleobotanical technique is the modern analog or NLR (nearest living relative) method. In this approach, the altitudinal ranges of modern species most similar to the fossil forms are used to establish the elevation consistent with the paleocommunity. Another method uses foliar physiognomy, that is, morphology of the leaves, to estimate the MAT of an upland flora and of a coeval coastal flora, then a terrestrial lapse rate is used to calculate the paleoelevation of the upland flora (Meyer, 1992; Wolfe, 1992). Another technique uses the foliar physiognomy to infer the moist static energy or enthalpy of the atmosphere (energy per unit mass) that varies with elevation (Forest et al., 1999). These techniques have been used to estimate the uplift history of the western United States from fossil floras (Wolfe et al., 1997, 1998; Chase et al., 1998).

Relatively little is known about the uplift history of the Central Andean Plateau. With a mean elevation of $3700 \mathrm{~m}$ it forms the second highest emergent plateau on Earth after the 
Tibetan Plateau. The three paleofloras that have been studied from this region, (i.e., the late Oligocene-early Miocene Chucal flora, the early-middle Miocene Potosí flora, and the middle Miocene Jakokkota flora), along with amounts of crustal shortening and the slope of paleosurfaces, suggest that more than half of the present elevation was created since $10 \mathrm{Ma}$ (Kennan, Lamb, and Hoke, 1997; Gregory-Wodzicki, 2000). If true, this figure would represent a major amount of uplift in the late Miocene-Pliocene, with considerable implications for biotic history and for computer modeling of global climatic change. However, the errors on these estimates are large, and additional independent data are needed to test the hypothesis of recent uplift.

In this study, we analyze new data from a fourth fossil locality, the Pislepampa flora from the Central Andes of Bolivia. Leaf remains were discovered at this site by E. W. Berry in the early part of the last century. We returned to his site and collected sediments that contained an assemblage of fossil pollen and spores. Plant microfossils have not been studied previously from any of the localities in Bolivia. First, we will discuss the floristic composition and probable age of the palynoflora. We then use the modern analog (NLR) method to assess the paleoclimate and paleoelevation represented by the assemblage, and will discuss the results in terms of their implications for the uplift history of the Central Andean Plateau.

\section{COLLECTING LOCALITY}

In Bolivia the Central Andean Plateau is composed of three morphotectonic provinces, which are from west to east, the Western Cordillera, consisting of volcanic peaks superimposed on a 4500-m high plateau; the Altiplano, a 250-km-wide, $3700 \mathrm{~m}$ high plateau with internal drainage; and the Eastern Cordillera, a rugged zone of high peaks and deep valleys. The Pislepampa site (Lat. $17^{\circ} 11^{\prime} \mathrm{S}$, Long. $66^{\circ} 02^{\prime} \mathrm{W}$ ) is located at an elevation of $\sim 3600 \mathrm{~m}$ in the Eastern Cordillera, $20 \mathrm{~km}$ northeast of Cochabamba (Fig. $1 \mathrm{a}, \mathrm{b})$. Directional markers are not prominent and they are often temporary, but directions provided by the local residents to the towns nearest the collecting locality are to go east on the main road from Cochabamba on the new road to Santa Cruz, through the toll booth, then immediately reverse back west to a dirt road that departs to the right (north) and continue toward the town of Palca. The collecting site is found along an arroyo about halfway between Palca and the small settlement of Pisle.

The Tertiary outcrops are small and discontinuous because of repeated glacial erosion and deposition. The site containing the plant fossils is only a few metres wide and $\sim 5 \mathrm{~m}$ in 
height. It consists of thin bands of lignite $2-10 \mathrm{~cm}$ in thickness, alternating with clays that contain organic debris, suggesting deposition in a lacustrine environment. Both the plant megafossils and microfossils occur in the clay layers.

The present vegetation of this site is puna (grassy páramo or alpine tundra), dominated here by the bunch grass Stipa $\underline{i c h u}$. The climate at Pislepampa is typical of equatorial regions in that the difference in the shortest and longest days is no greater than $3 \mathrm{~h}$, and the daily variations of temperature are larger than the yearly variations. From climatic data in Roche (1993), the MAT for Pislepampa is estimated at $\sim 10^{\circ} \mathrm{C}$, and the MAP (mean annual precipitation) is $\sim 800$ $1000 \mathrm{~mm}$, with $80 \%$ of the total occurring during the summer months of December-March. A marked dry season occurs during the winter months of May to September.

This is the site from which Berry (1922a) originally described the Pislepampa flora (which he renders as Pisllypampa, likely due to phonetic spelling). It is listed as Pisle on the map Estancia Cuarto Esquinas, Hoja 6342 II (Carta Nacional, Bolivia, escala 1:50000). He regarded the age as Pliocene "from a consideration of all the available facts" (p. 156) and slightly older than the Potosí flora, now radiometrically dated as between 13.8 and 20.7 Ma (GregoryWodzicki, McIntosh, and Velásquez, 1998). The facts available to him at the time consisted mostly of a comparison with other floras of estimated Pliocene age from South America based on the modern nature of the floras and their association with volcanic ash regarded as likely Neogene in age. The age is poorly constrained, and rocks suitable for radiometeric dating have not been found associated directly with the Pislepampa flora.

\section{MATERIALS AND METHODS}

The sediments were processed according to standard procedures (Gray, 1965; Traverse, 1988). The samples were macerated in a mortar and pestle and placed successively in HCL (1 h), $\mathrm{HF}(1 \mathrm{~h})$, and $\mathrm{HNO}_{3}$ (overnight), with four rinses of distilled water between each acid treatment. The residues were acetolyzed (nine parts of acetic anhydride to one part of concentrated $\mathrm{H}_{2} \mathrm{SO}_{4}$ ) with rinses in glacial acid before and after acetolysis, mounted unstained in glycerine jelly, and sealed with CoverBond. Some samples were processed at BP-AMOCO using heavy liquid flotation. The specimens were examined and photographed at 400x magnification using a Leitz Orthoplan Photomicroscope and TMAX 100 black and white film. Identifications were made by comparisons with a pollen and spore reference collection of $\sim 24$ 000 slides and through published illustrations and descriptions. Location of the specimens on the 
slides is by ESF (England slide finder) coordinates. Although slides from several samples were examined, all specimens described and illustrated here are from sample 6, slide 1. Slides, residues, unprocessed samples, negatives, and duplicate prints are in the palynological collections at Kent State University. Coordinates for the Pislepampa site were verified with a Magellan Geographic Positioning System ColorTrak Satellite Navigator.

\section{COMPOSITION}

Thirty-three types of pollen grains and spores are recognized for the Pislepampa flora and these are listed in Table 1 along with their percentages and the elevational range of those genera typical of a relatively restricted altitudinal zone. Ecological information for the ferns and allied groups is based primarily on Tryon and Tryon (1982) and for the woody plants of Bolivia on Killeen, García E., and Beck (1993). The age, location, and references to other fossil floras cited in the text are given in Table 2.

Lycopsida--Isoetes (Isoetaceae, microspores; Fig. 2). Amb reniform; monolete, laesura located on concave side of spore, 25-27 $\mu \mathrm{m}$ long, inner margin entire; densely echinate, echinae fine, minute $(\sim 1 \mu \mathrm{m}$ long), curved; size 35-40 $\mu \mathrm{m}$. England Slide Finder coordinates D-45, 3-4.

$\underline{\text { Isoetes }}$ is a widespread genus of about 150 heterosporous species. It is common in South America and is particularly abundant in aquatic habitats or on saturated soils in the Andean region. Similar densely echinate microspores, appearing almost hirsute at LM magnification of 400x, are illustrated with SEM in Tryon and Lugardon (1991, p. 624, figs. 8, 10). Microfossils of Isoetes have not been identified previously from the Tertiary of Latin America.

Lycopodium type 1 (Lycopodiaceae; Fig. 3). Amb triangular to oval-triangular, apices rounded; trilete, laesurae straight, narrow, 15-20 $\mu \mathrm{m}$ long, extending to spore margin, inner margin entire; distal surface with numerous pits $\sim 1 \mu \mathrm{m}$ in diameter (foveolate), proximal surface laevigate; wall $\sim 2 \mu \mathrm{m}$ thick; size 34-36 $\mu \mathrm{m}$. ESF K-35, 4.

Tryon and Lugardon (1991, pp. 590-594) treat species with foveolate (pitted) and

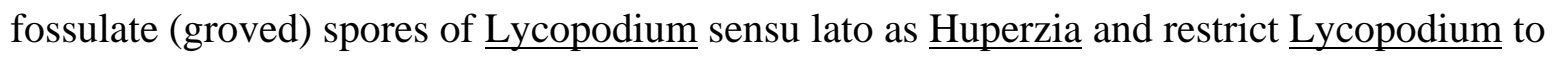
species with reticulate spores. Species represented by pitted spores are widespread in upland Central America and Andean South America. They are frequent but never abundant in Tertiary deposits of northern Latin America and have been reported from the Paraje Solo, La Boca, Uscari, Gatun, and Culebra floras. 
Lycopodium type 2 (Fig. 4). Amb triangular to oval-triangular, apices rounded; trilete, laesurae straight, narrow, 15-19 $\mu \mathrm{m}$ long, extending to or nearly to spore margin, inner margin entire; distal surface fossulate, proximal surface laevigate; wall $2 \mu \mathrm{m}$ thick; size 32-36 $\mu \mathrm{m}$. ESF K-43, 1-2.

Fossulate spores of Lycopodium (Huperzia) are known also from the Padre Miguel, Culebra, Uscari, La Boca, and San Sebastian floras.

Lycopodium type 3 (Fig. 5). This specimen may represent a smaller version (26 $\mu \mathrm{m})$ of Lycopodium type $2(32-36 \mu \mathrm{m})$ as seen from the proximal face. ESF D-44, 2-4.

Filicineae--Cnemidaria (Cyatheaceae; Fig. 6). Amb oval-triangular, apices rounded; trilete, laesurae straight, narrow, 15-20 $\mu \mathrm{m}$ long, extending to or nearly to spore margin, inner margin entire, bordered by faint lip 3-5 $\mu \mathrm{m}$ wide; foveolate with three large pits $\sim 8-10 \mu \mathrm{m}$ in diameter between the apices at the spore margin; 2-3 $\mu \mathrm{m}$ thick; size 35-40 $\mu \mathrm{m}$. ESF P-46, 1-3.

In South America Cnemidaria is mostly Andean in distribution growing in wet montane forests at low to mid-elevations. In northern Latin America it occurs in the Gatun, San Sebastian, Paraje Solo, and Uscari floras.

Cyathea type 1 (Cyatheaceae; Fig. 7). Amb triangular to concavo-triangular, apices rounded; trilete, laesurae straight, narrow, $15 \mu \mathrm{m}$ long, extending to or nearly to spore margin, inner margin entire; laevigate; wall $2 \mu \mathrm{m}$ thick; size 30-35 $\mu \mathrm{m}$. ESF E-42,2.

These generalized, smooth, trilete fern spores are abundant in the Pislepampa flora and

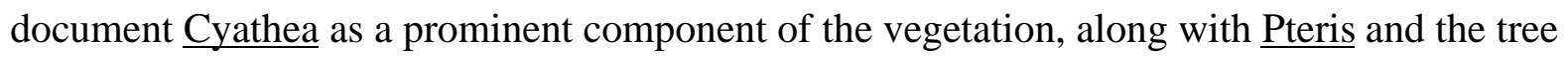

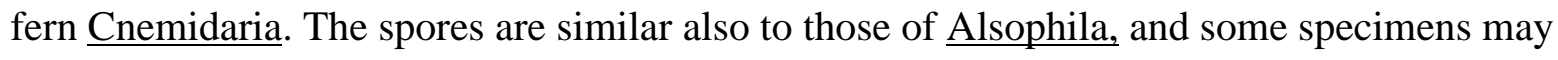
represent that genus. However, in the microfossils a lip surrounding the laesurae is faint to absent and in this regard they most closely resemble Cyathea, although this character does vary among individual species. The spore morphology in the Cyatheaceae and other ferns has been studied by various authors (e.g., Gastony, 1974; Gastony and Tryon, 1976; Tryon and Lugardon, 1991), but there is still a lack of correlation between distinctive spore morphology and some family/generic delineations.

Spores of the type illustrated in Fig. 7 have been reported also from the Gatun, Paraje Solo, La Boca, Cucaracha, Culebra, and San Sebastian floras.

Cyathea type 2 (Fig. 8). Amb triangular to oval triangular, margin lobate due to projecting sculptural elements, apices rounded; trilete, laesurae straight, narrow, 15-20 $\mu \mathrm{m}$ long, 
extending three-fourths distance to spore margin, inner margin entire; distal surface with conspicuous mound-like verrucae 5-6 $\mu \mathrm{m}$ in diameter, smooth, proximal surface more laevigate; wall 2-3 $\mu \mathrm{m}$ thick; size 40-50 $\mu \mathrm{m}$. ESF E-34.

Spores of this type are illustrated by Tryon and Lugardon (1991, p. 263), and as fossils they are known from the Gatun flora.

Cyathea type 3 (Fig. 9). This spore is similar to Cyathea type 2 but the verrucae are smaller $(3-4 \mu \mathrm{m})$. Spore $40 \mu \mathrm{m}$, ESF Y-41.

Grammitis (Grammitidaceae; Fig. 10). Amb oval-triangular; trilete, laesurae straight, narrow, 20-22 $\mu \mathrm{m}$ long, extending to spore margin, inner margin entire, bordered by narrow $(\sim 2$ $\mu \mathrm{m})$ thickened margin; densely aggregated, minute baculae with occasional echinae; wall $\sim 2 \mu \mathrm{m}$ thick; size 40-44 $\mu \mathrm{m}$. ESF R-41.

These epiphytic ferns occur in mossy substrates and are distributed from Mexico southward to Argentina and Chile (Tryon and Lugardon, 1991, pp. 363-367). Similar spores are known from the Gatun Formation, although they are somewhat more distinctly baculate.

Hymenophyllum (Hymenophyllaceae; Fig. 11). Amb oval-triangular; trilete, laesurae straight, narrow, 14-16 $\mu \mathrm{m}$ long, extending to spore margin, inner margin entire, bordered by narrow $(\sim 2 \mu \mathrm{m})$ thickened margin; minutely echinate; wall $2 \mu \mathrm{m}$ thick; size $32-34 \mu \mathrm{m}$. ESF K$30,1-3$.

These spores are smaller than the similar ones of Grammitis and are more distinctly and consistently echinate (cf. Tryon and Lugardon, 1991, p. 89).

Pteris (Pteridaceae; Figs. 12, 13). Amb triangular, bordered by conspicuous flange $\sim 6$ $\mu \mathrm{m}$ wide, apices rounded; trilete, laesurae straight, narrow, 14-20 $\mu \mathrm{m}$ long, extending nearly to spore margin, inner margin entire, lip obscure; distal surface with low, faint verrucae, proximal surface laevigate; wall 2-3 $\mu \mathrm{m}$ thick; size 34-40 $\mu \mathrm{m}$. ESF F-46, 1-3 (Fig. 12), K-30, 3-4 (Fig. $13)$.

Pteris is widely distributed in Latin America and is especially abundant in the Andes Mountains (Tryon and Lugardon, 1991, p. 188). It is frequent in Tertiary deposits of Latin America and occurs in virtually all floras studied from the Caribbean Basin (Table 2) and adjacent northern South America (e.g., Maracaibo, Falcon, Eastern Basins of Colombia; Lorente, 1986). 
Two unidentified trilete fern spores are shown in Fig. 14 (laevigate, 35-37 $\mu \mathrm{m}$, ESF G43, 103) and Fig. 15 (laevigate, $28 \mu \mathrm{m}$, ESF M-31, 1).

Danaea (Marrattiaceae; Figs. 16, 17). Amb reniform to circular; monolete, laesura straight, narrow, 18-20 $\mu \mathrm{m}$ long, extending nearly to spore margin; inner margin entire; echinate, echinae $\sim 2 \mu \mathrm{m}$ long, relatively densely arranged; wall $2 \mu \mathrm{m}$ thick; size $26-28 \mu \mathrm{m}$. ESF L-31, 24.

At LM magnifications the circular specimens (Fig. 16) are similar also to $\underline{\text { Ctenitis }}$ (Dryopteridaceae; cf. Tryon and Lugardon, 1991, p. 460 and p. 48), while the reniform specimens (Fig. 17) are most similar to Danaea. They also resemble Megalastrum and, as noted by Tryon and Lugardon (1991, pp. 456, 459-460), Ctenitis and Megalastrum are closely related. All three genera are represented in the modern flora of Bolivia, and as fossils they are known from the Gatun and Culebra floras.

In addition to the fern spores that can be recognized to genus, there is the usual cadre of generalized monolete forms found in Neotropical Tertiary floras that are similar to various Blechnaceae, Polypodiaceae, Pteridaceae, and other families. Examples include monolete fern spore type 1 (large, 60 x $48 \mu \mathrm{m}$, ESF U-37, Fig. 18), type 2 (smaller, 49-53 x 28-31 $\mu \mathrm{m}$, laevigate, ESF U-35, Fig. 19), type 3 (faintly verrucate, 52-55 x 27-31 $\mu \mathrm{m}$, ESF F-35, Fig. 20), and type 4 (coarsely verrucate, $42-47$ x 25-29 $\mu \mathrm{m}$, ESF F-35, Fig. 21). All these monolete spore types range widely both geographically and stratigraphically in Latin American Tertiary deposits and are of limited value for paleoenvironmental reconstructions.

Gymnospermae--Podocarpus (Podocarpaceae; Fig. 22). Monocolpate, colpus situated between air sacs on lower (proximal) surface of grain, margin diffuse, 22-26 $\mu \mathrm{m}$ long; vesiculate, body amb circular, finely verrucate, $28-31 \mu \mathrm{m}$ in diameter, wall $\sim 2 \mu \mathrm{m}$ thick, air sacs 2 , hemispheric, 23-27 x 31-34 $\mu \mathrm{m}$ in diameter, large in relation to body size, irregularly reticulate, muri low, narrow $(1 \mu \mathrm{m})$, smooth, lumina irregular in shape and diameter (larger $\sim 5 \mu \mathrm{m})$; overall dimensions (including air sacs) 52-55 x 39-43 $\mu \mathrm{m}$. ESF F-34, 2-4.

Podocarpus presently occurs in the Bolivian cloud forest at elevations mostly between about 1700 and $3400 \mathrm{~m}$. Prumnopitys is another genus of the family that occurs in Bolivia at about the same elevations, but pollen was not available for comparison. Pollen of Podocarpus has been reported from the San Sebastian, Paraje Solo, Gatun, and La Quinta floras, and possibly occurs in other Oligo-Miocene floras of Chiapas, Mexico (Tomasini-Ortiz and Martínez- 
Hernández, 1984) in northern Latin America. It is known also from Neogene sediments in the high plain of Bogotá, Colombia (Wijninga, 1996).

Angiospermae (monocots)--Gramineae (Fig. 23). Spherical, amb circular; monoporate, pore circular, 2-3 $\mu \mathrm{m}$ in diameter, inner margin entire, surrounded by annulus 3-4 $\mu \mathrm{m}$ wide; psilate to scabrate; tectate, wall $2 \mu \mathrm{m}$ thick, homogeneous (400x magnification); size 32-36 $\mu \mathrm{m}$. ESF X-28, 4.

The Gramineae are a stenopalynous family, and, with the exception of the large pollen of $\underline{\text { Zea, }}$ individual genera cannot be distinguished on the basis of pollen characters. Grasses occur in all vegetation types in Bolivia, and grass pollen is frequent but not abundant throughout Neotropical Tertiary deposits from the Paleocene to Recent.

Palmae (Fig. 24). Cuniform; monocolpate, colpus straight, $36 \mu \mathrm{m}$ long, extending nearly entire length of grain, inner margin entire; scabrate stectate, wall $2 \mu \mathrm{m}$ thick, columellae just evident (400x magnification); size 42 x $35 \mu \mathrm{m}$ (widest part just off equator of grain). ESF Z-44, $3-4$.

This generalized type of palm pollen is widespread in Neotropical Tertiary deposits and cannot be identified to genus. Twenty-six genera are recognized for Bolivia (Killeen, García E., and Beck, 1993). They occur in several communities and range from the lowland bosque húmedo tropical to the bosque montano de Yungas at 1000-3200 m.

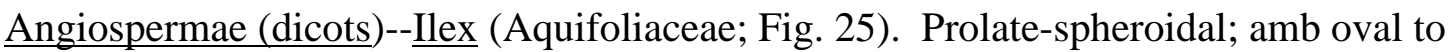
nearly circular; tricolporoidate, colpi equatorially arranged, meridionally elongated, equidistant, straight, 19-23 $\mu \mathrm{m}$ long, inner margin entire, pore poorly developed, frequently obscure, situated at mid-point of colpus; intectate, clavate, wall $3 \mu \mathrm{m}$ thick; size 28-31 x 24-26 $\mu \mathrm{m}$. ESF L-41, 3.

Ilex is represented by 23 species in Bolivia (Killeen, García E., and Beck, 1993). They range widely through several vegetation types and from 180 to $4000 \mathrm{~m}$ in elevation. However, Ilex is most typical of mesic habitats at middle elevations including the cloud forest. Pollen of Ilex is frequent but never abundant in Tertiary palynofloras of Latin America.

cf. Oreopanax (Araliaceae; Fig. 26). Prolate; tricolporate, colpi equatorially arranged, meridionally elongated, equidistant, straight, $24 \mu \mathrm{m}$ long, inner margin entire, pores slightly elongated equatorially, 2 × $3 \mu \mathrm{m}$, situated at mid-point of colpus; finely reticulate, diameter of lumina approximately equal to width of muri $(\sim 1 \mu \mathrm{m})$, muri smooth, lumina polygonal; tectate- 
perforate, wall $\sim 3 \mu \mathrm{m}$ thick, columellae evident in median optical section (400x magnification); size 29-31 x 17-20 $\mu \mathrm{m}$. ESF N-38.

Fourteen species of Oreopanax are listed for Bolivia (Killeen, García E., and Beck, 1993). They range in elevation from 1100 to $3600 \mathrm{~m}$ and are a common member of the cloud forest. The pollen of Oreopanax is similar to that of Dendropanax and differs only in minor quantitative features, hence, the "cf." identification. Pollen of Oreopanax has not been reported previously from the Tertiary of Latin America.

Cavanillesia (Bombacaceae; Fig. 27). Oblate, amb oval-triangular, apices rounded; tricolpate, colpi located in inter-apical area, short (6-8 $\mu \mathrm{m}$, apex to margin of grain), equatorially arranged, meridionally elongated, equidistant, inner margin entire, bordered by costae colpi $\sim 2-3$ $\mu \mathrm{m}$ wide (obscure); finely reticulate at poles, diameter of lumina (1-2 $\mu \mathrm{m})$ equal to or slightly greater than width of muri $(\sim 1 \mu \mathrm{m})$, becoming finer at apices, muri smooth, straight, lumina circular to slightly polygonal; tectate-perforate, wall 2-3 $\mu \mathrm{m}$ thick; size 30-35 $\mu \mathrm{m}$. ESF S-46.

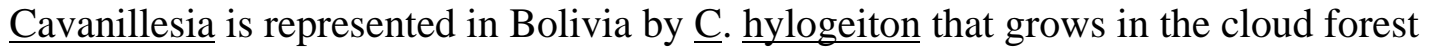
(bosque húmedo; Killeen, García E., and Beck, 1993, p. 154) at elevations between 250 and 850 $\mathrm{m}$. It is a large tree that also occurs "in seasonally dry rain forest including parts of the western Amazon, at lower altitudes than the other taxa mentioned here" (M. Nee, New York Botanical Garden, personal communication, 2000).

cf. Pereskia (Cactaceae; Fig. 28). Oblate-spheroidal, amb polygonal; periporate, pores evenly distributed (6-8 $\mu \mathrm{m}$ apart), circular to slightly elongated, 7-9 $\mu \mathrm{m}$ in diameter, margin diffuse; tectate, wall 2-3 $\mu \mathrm{m}$ thick, columellae evident in median optical section (400x magnification); size $40 \mu \mathrm{m}$. ESF O-44.

Twelve genera of woody Cactaceae are reported in Bolivia by Killeen, García E., and Beck (1993), and Navarro (1996) lists 27 genera of Cactaceae, but only two of these (Opuntia, $\underline{\text { Pereskia) }}$ are presently available in our reference collection. The specimen is most similar to Pereskia represented by three species in Bolivia. These range from 350 to $2100 \mathrm{~m}$ in elevation and are most common in the bosque seco, but $\underline{\mathrm{P}}$. sacharosa ranges into the cloud forest.

Compositae type 1 (Fig. 29). Prolate-spheroidal; tricolporoidate, colpi equatorially arranged, meridionally elongated, equidistant, straight, 19-21 $\mu \mathrm{m}$ long, pore obscure; echinate, echinae short $(\sim 2 \mu \mathrm{m})$, moderately dense (distance between spines $\sim 4 \mu \mathrm{m}$; tectate, wall $2 \mu \mathrm{m}$ thick; size (excluding spines) 24-26 x 20-22 $\mu \mathrm{m}$. ESF S-33, 3. 
Compositae type 2 (Fig. 30). These grains are similar to Compositae type 1 except that the spines are considerably longer $(\sim 6 \mu \mathrm{m})$. Size (excluding spines) $25-28 \mu \mathrm{m}$. ESF J-42, 3-4. cf. Compositae (Vernonieae; Fig. 31). These specimens are of only fair preservation. They resemble the coarsely reticulate grains of some Vernonieae (cf. Roubik and Moreno P., 1991, p. 202, fig. 526), but differ in that spines are not clearly evident along the margin of the grain, hence, the cf. identification. Size $34 \mu \mathrm{m}$, ESF O-43, 2-4.

Members of the Compositae range through all vegetation types in Bolivia. As fossils they occur in most Tertiary floras of Latin America beginning in the Oligo-Miocene.

Ericaceae (Fig. 32). Tetrahedral tetrad; individual grains nearly spherical (compressed in tetrad); tricolpate, colpi equatorially arranged, meridionally elongated, equidistant, straight, inner margin entire, bordered by narrow margo $\sim 2 \mu \mathrm{m}$ wide, colpi shared (continuous across contact between grains); psilate; tectate, wall $2 \mu \mathrm{m}$ thick, homogeneous (400 x magnification); size (individual grains) $\sim 15 \mu \mathrm{m}$, (tetrads) 28-30 $\mu \mathrm{m}$; ESF K-41, 1-3.

The Ericaceae are represented by ten genera in Bolivia (Killeen, García E., and Beck, 1993). Most grow in moist habitats between 1200 and $3650 \mathrm{~m}$, and they are abundant in the cloud forest. Pollen of the Ericaceae is also known from the Gatun flora.

Tetrorchidium (Euphorbiaceae; Fig. 33). Oblate-spheroidal, amb circular; tricolpate, colpi straight ${ }_{s} 10-12 \mu \mathrm{m}$ long (apex to margin of grain), equatorially arranged, meridionally eongated, equidistant, inner margin finely dentate; intectate, finely baculate to nearly echinate, wall $\sim 1.5 \mu \mathrm{m}$ thick; size $28 \mu \mathrm{m}$. ESF R-45, 3.

Two species of Tetrorchidium are known for Bolivia (T. macrophyllum; $\underline{\text { T. }}$ rubrivenium) growing around $1900 \mathrm{~m}$ and $450 \mathrm{~m}$, respectively (Killeen, García E., and Beck, 1993). Pollen of the genus has been reported previously from the Tertiary Culebra, Paraje Solo, and San Sebastian floras.

Unknown 1 (Fig. 34). Oblate to oblate spheroidal; amb circular; inaperturate (apertures obscure); intectate, clavate, wall $2 \mu \mathrm{m}$ thick; size $38 \mu \mathrm{m}$. ESF T-36, 4.

The structure appearing like a trilete scar on the grain is a fold.

Unknown 2 (Fig. 35). Oblate, amb triangular; tricolpate, colpi equatorially arranged, meridionally elongated, equidistant, straight, $9 \mu \mathrm{m}$ long (apex to margin of grain), bordered by narrow margo $1 \mu \mathrm{m}$ wide, inner margin entire; psilate; tectate, wall $2 \mu \mathrm{m}$ thick, homogeneous (400x magnification); size $28 \mu \mathrm{m}$. ESF X-32. 
Unknown 3 (Fig. 36). Prolate; tricolporate, colpi equatorially arranged, meridionally elongated, equidistant, straight, $28 \mu \mathrm{m}$ long, extending nearly entire length of grain, inner margin entire, bordered by costae colpi $3 \mu \mathrm{m}$ wide; psilate to faintly scabrate; tectate, wall $2 \mu \mathrm{m}$ thick, homogeneous (400x magnification); size 36 x $27 \mu \mathrm{m}$.

This specimen resembles Oreopanax (Fig. 26), but the columellae are much finer and the sculpture is scabrate to possibly faintly striate. It may represent a member of the Anacardiaceae.

\section{DISCUSSION}

Stratigraphy and age-The Pislepampa section (Fig. 37) consists of alternating sequences of tuff (water-lain volcanic ash), lignite, and clay. This sequence is typical of lacustrine (lake, swamp) depositional settings in a volcanically active region. The megafossils likely represent vegetation growing along or near the lake margin. The microfossils include gravity-dispersed (e.g., fern spores) and wind-dispersed (e.g., Podocarpus) types and record the vegetation both along the lake margin and in the adjacent uplands.

In the absence of rocks suitable for radiometric dating, only an approximate age can be given for the Pislepampa flora. The assemblage is clearly Neogene in age because all of the plant microfossils identified presently grow in the modern cloud forest of Bolivia. The Compositae are useful in providing a maximum age estimate because in Latin America they first appear in the Oligo-Miocene and do not become frequent or diverse until the middle to late Miocene. The complex Vernonieae types appear even later, in the Mio-Pliocene. Compositae pollen is common in the Pislepampa sediments, and Vernonieae is present.

The minimum age of the Pislepampa assemblage cannot be established on the basis of the palynological data because all of the palynomorphs range into modern times. The fossiliferous sediments have a dip of $20^{\circ}$. If regional, this tilt would suggest that they were deposited before the end of crustal shortening in the Eastern Cordillera, dated as around $10 \mathrm{Ma}$ (Allmendinger et al., 1997). However, outcrop is very limited, and the tilt of the sediments could be local.

\section{Modern vegetation and paleocommunities--The modern vegetation of Bolivia is} described in several publications including Nee (1999), Killeen, García E., and Beck (1993), and Rivera et al. (1996). For consistency the classification of Killeen, García E., and Beck (1993) is used here, and by that system the vegetation can be grouped into 14 communities (Fig. 38). In the north are the lowlands of Amazonia (bosque Amazónico) with patches of mostly edaphically controlled drier campos cerrados and campos Amazónicos. In the northeast the Andes 
Mountains trend NW-SE and intercept the moisture-laden winds coming off Amazonia. There is high precipitation along the slopes, and the vegetation types are bosque húmedo de llanura and bosque húmedo de Escudo Precámbrico. At about Santa Cruz, the Andes Mountains turn N-S, away from the moist easterly winds (Fig. 1a, b), and the climate becomes much drier. Here the vegetation types are bosque semideciduo Chiquitano with patches of campos cerrados, bosque seco Chaqueño, bosque Serrano Chaqueño, and sabanas húmedas. At the higher elevations precipitation begins to increase and supports the ceja de monte Yungueña (yungas), bosque Tucumano-Boliviano, and eventually the bosque montano húmedo (bosque nublado, cloud forest) where fog is an important supplement to precipitation. Within this zone are interandean valleys that are cut off from sources of moisture and support the valles secos interandinos vegetation. At the very highest elevations is the puna (páramo) of the altiplano.

Of particular relevance to the Pislepampa flora is the bosque montano húmedo (Killeen, García E., and Beck, 1993; bosque nublado of Nee, 1999; bosque húmedo montañoso of Rivera et al., 1996; cloud forest; Fig. 39). Of the 14 genera identified for the Pislepampa flora, all are characteristic of that community (Table 1). Although these genera individually may extend into other communities, as a group they identify the cloud forest as the principal paleocommunity represented in the Pislepampa plant microfossil flora.

Paleoelevation and paleoclimate-Genera of the bosque montano húmedo identified from the Pislepampa assemblage grow mostly between 1200 and $3200 \mathrm{~m}$ in elevation, and the plant microfossils provide little evidence for positioning the Pislepampa flora more precisely within that broad range. The presence of Palmae and possibly Cavanillesia pollen suggest deposition near the lower limits of the cloud forest, but they are rare in the fossil flora. The Palmae especially occur in several vegetation types and have a wide elevational range.

The plant megafossils, however, provide additional evidence for estimating the paleoelevation of the Pislepampa flora. As noted by Berry (1922a), the leaves are mostly large, and perusal of the plates and descriptions shows that all the specimens are entire margined. It would be an over-interpretation of the data to try and derive a quantitative estimate for the paleoelevation because of the small size of Berry's sample, which only includes leaves of 16 angiosperm species; it is preferable to have at least 20 species of woody angiosperms when using leaf morphology to estimate climate (Wolfe, 1993). However, the fact that $100 \%$ of the angiosperm leaves are of entire-margined species identifies the fossil flora with the modern 
moist lowland tropical vegetation in which typically $75 \%$ or more of the species have entire margins (Bailey and Sinnott, 1915; Wolfe, 1979, 1993). Thus, the leaf remains suggest that the Pislepampa flora grew at the lower limits of the cloud forest where elements of the bosque Amazónico extended upward along the eastern slopes of the proto-Andes Mountains. It should be noted that such paleoenvironmental reconstructions based on plant megafossils do not assume ecological equivalency of the taxa over long periods of time, and are independent of the identification (viz., establishing the biological affinities of the specimens). Identification of tropical leaf material in the early literature has proven notoriously unreliable (Dilcher, 1971, 1973). None of the megafossil taxa identified by Berry (1922a) were encountered as microfossils, although some of his fern genera may be represented among the generalized monolete and trilete fern spore types.

Thus, the sedimentological, plant microfossil, and plant megafossil evidence collectively indicate deposition around a lake bordered by elements of the bosque Amazónico with a version of the bosque montano húmedo growing on the surrounding slopes. This would place the paleoelevation of the Pislepampa flora at 1200 to $1400 \mathrm{~m}$ (Table 3), which represents the modern-day lower elevation limits of the bosque montano húmedo. This estimate is very similar to Berry's (1922a) elevation estimate of $<1500 \mathrm{~m}$ for the Pislepampa flora based on the modern affinities of the leaf remains.

This elevation estimate is only valid if the latest Mio-Pliocene climate was similar to the modern climate. For instance, a global cooling trend since the Miocene could explain the presence at high elevations of what today are low-elevation forests. Over the long term, the assumption of similar climate appears to be reasonable; marine isotope records suggest that latest Miocene and Pliocene sea surface temperatures for the eastern equatorial Pacific were similar to those of today (Hays, Pisias, and Roelofs, 1989; Dowsett, Barron, and Poore, 1996; King, 1996).

However, because the palynoflora probably represents a short period of time, one also must take into account short-term temperature fluctuations. Marine isotope data suggest that in the Pliocene, temperatures varied on the order of $1.5^{\circ}-4^{\circ} \mathrm{C}$ (King, 1996). Using the global mean terrestrial lapse rate of $0.6^{\circ} \mathrm{C} / 100 \mathrm{~m}$ (Meyer, 1992), this range of temperature error translates to a range of elevation error of $\pm 250-700 \mathrm{~m}$ (2 SD).

Other possible errors stem from the assumption that as the fossil taxa evolved into their modern relatives, their ecological ranges did not change. This may not be correct, especially as 
one goes further back in time (Mosbrugger and Utescher, 1997; Parish, 1998, p. 150). However, this theoretical limitation has been stated, and perhaps overstated (see Graham, 1999a, pp. 106109), as applied to assemblages of species (as opposed to individual taxa) and for relatively recent (Neogene) time.

When interpreting this elevation estimate in terms of the uplift history of the Central Andean Plateau, one must make the distinction between surface uplift and rock uplift. Surface uplift represents the displacement of the average elevation of the landscape on a regional scale $\left(10^{3}-10^{4} \mathrm{~km}^{2}\right)$ with respect to mean sea level, while rock uplift is a local displacement of material with respect to sea level. Rock uplift only reflects regional surface displacements if no erosion occurs (England and Molnar, 1990). This distinction is significant because surface uplift reflects driving forces due to orogenesis, that is, mountain-building, while rock uplift can reflect both orogenesis and isostatic rebound.

Because of the small amount of erosion, and likely isostatic rebound, that has occurred in the arid Altiplano since the late Miocene (Isacks, 1988), one can use paleoelevation data from this region to reconstruct surface uplift. However, for the last 10 MA, Masek et al. (1994) estimate that 2-6 km of erosion has taken place in the Eastern Cordillera north of $19^{\circ} \mathrm{S}$, which would suggest between $\sim 200$ and $1200 \mathrm{~m}$ of isostatic rebound of the remaining surfaces. Thus, there was $~ 1000-2200$ m of surface uplift after deposition of the Pislepampa flora, which represents $40-65 \%$ of the total surface uplift (Table 4, Fig. 40). This suggests that a significant amount of uplift occurred in the late Miocene and Pliocene. The paleoelevation of the Pislepampa flora is consistent with other paleoelevation estimates from fossil floras (Table 3), and evidence from paleosurfaces (Table 4) suggests that at least half of the uplift of the Central Andean Plateau took place after 10 Ma (Gregory-Wodzicki, 2000).

An approximation of the paleoclimate can be determined by comparison with data from modern climate stations in Bolivia located in the bosque montano húmedo. Rivera et al. (1996) present climate data that suggest a temperature between $10^{\circ}-20^{\circ} \mathrm{C}$ and rainfall between 1000 and $3500 \mathrm{~mm}$. Because the Pislepampa flora is located in the lower part of the forest, its paleotemperature would have been in the warmer end of the range, that is, $20^{\circ} \mathrm{C}$. Its rainfall is estimated in the lower portion of the range between $\sim 1000$ and $1500 \mathrm{~mm}$. Present mean annual rainfall at La Paz $(3600 \mathrm{~m})$ is $\sim 270 \mathrm{~mm}$, and at Cochabamba $(2534 \mathrm{~m})$ it decreases to $\sim 230 \mathrm{~mm}$. 
This paleotemperature is similar to the paleotemperature estimated from the Potosí and Jakokkota floras based on foliar physiognomy, but the estimated rainfall is significantly higher. The large size of the leaf remains at Pislepampa is consistent with higher estimates of rainfall.

The emerging picture of paleoenvironments for the central Andes Mountains of Bolivia, based on paleobotanical evidence, is complicated by two factors. First is the lack of radiometric dates for the Pislepampa flora. The second is the difficulty of disentangling the effects of uplift versus climatic change on MATs and subsequent calculations of paleoelevation. However, the analysis of a new assemblage of pollen and spores from Pislepampa suggest the following conclusions:

1) The Pislepampa flora is characterized by a large variety of fern spores (70.6\%), probably reflecting local deposition and some differential preservation, and pollen types indicative of the modern bosque montano húmedo (cloud forest) from the eastern slopes of the Andes. The community presently grows between elevations of 1200 and $3200 \mathrm{~m}$, with MATs between $10^{\circ}$ and $20^{\circ} \mathrm{C}$ and MAP between 1000 and $3500 \mathrm{~mm}$.

2) Based on the diversity of the Compositae, the maximum age of the flora is middle to late Miocene. The presence of a complex-type Compositae (Vernonieae) form suggests a maximum age as young as the Miocene-Pliocene transition, that is, 6-7 Ma.

3) The Pislepampa flora probably grew near the lower border of the bosque montano húmedo because of the large number of species with entire-margined leaves documented by Berry (1922a). Thus, it probably had a paleoelevation of between 1200 and 1400 $\mathrm{m}$, assuming a similar climate in the Miocene-Pliocene, a MAT of $\sim 20^{\circ} \mathrm{C}$, and MAP between 1000 and $1500 \mathrm{~mm}$. Given the magnitude of short-term temperature fluctuations and evolution, the elevation estimate should be considered to have an error of at least $\pm 1000 \mathrm{~m}$ (2 SD).

4) When the total uplift is corrected for probable amounts of erosionally driven isostatic rebound, the paleoelevation estimate suggests that from one-third to one-half of the uplift of the Eastern Cordillera had occurred by the beginning of the Pliocene. This estimate is consistent with other paleoelevation estimates from the Central Andes. 


\section{LITERATURE CITED}

Allmendinger, R. W., T. E. Jordan, S. M. Kay, and B. L. Isacks. 1997. The evolution of the AltiplanoPuna plateau of the central Andes. Annual Reviews of Earth and Planetary Science 25: 139-174.

Bailey, I. W., and E. W. Sinnott. 1915. A botanical index of Cretaceous and Tertiary climates. Science 41: 831-834.

Berry, E. W. 1922a. Pliocene plants from eastern Bolivia. Johns Hopkins University Studies in Geology 4: 145-204.

Berry, E. W. 1922b. Late Tertiary plants from Jancocata, Bolivia. Johns Hopkins University Studies in Geology 4: 205-221.

Berry, E. W. 1939. The fossil flora of Potosí, Bolivia. Johns Hopkins University Studies in Geology 13: 9-68.

Broccoli, A. J., and S. Manabe. 1997. Mountains and midaltitude aridity. In W. F. Ruddiman [ed.], Tectonic uplift and climate change, 89-121. Plenum Press, New York, New York, USA.

Charrier, R., R. Muñoz, and S. Palma-Heldt. 1994. Edad y contenido paleofloristico de la Formación Chucal y condiciones paleoclimaticas para el Oligoceno tardio-Miceno inferior en el Altiplano de Arica, Chile. Proceedings of the Seventh Congreso Geológico Chileno (Concepción, Chile, 1994) 1: 434-437.

Chase, C. G., K. M. Gregory-Wodzicki, J. T. Parrish-Jones, and P. DeCelles. 1998. Topographic history of the western cordillera of North America and controls on climate. In T. J. Crowley and K. Burke [eds.], Tectonic boundary conditions for climate model simulations, 73-99. Oxford Monographs on Geology and Geophysics 39. Oxford University Press, New York, New York, USA.

Dilcher, D. L. 1971. A revision of the Eocene flora of southeastern North America. Palaeobotanist 20: 7-18.

Dilcher, D. L. 1973. A paleoclimatic interpretation of the Eocene floras of southeastern North America. In A. Graham [ed.], Vegetation and vegetational history of northern Latin America, 39-60. Elsevier, Amsterdam, The Netherlands.

Dowsett, H., J. Barron, and R. Poore. 1996. Middle Pliocene sea surface temperatures: a global reconstruction. Marine Micropaleontology 27: 13-25.

England, P., and P. Molnar. 1990. Surface uplift, uplift of rocks, and exhumation of rocks. Geology 18: $1173-1177$.

Forest, C. E., J. A. Wolfe, P. Molnar, and K. Emanuel. 1999. Paleoaltimetry incorporating atmospheric physics and botanical estimates of paleoclimate. Bulletin of the Geological Society of America 111: 497-511.

Gastony, G. J. 1974. Spore morphology in the Cyatheaceae. I. The perine and sporangial capacity: general considerations. American Journal of Botany 61: 672-680.

Gastony, G. J., and R. M. Tryon 1976. Spore morphology in the Cyatheaceae. II. The genera Lophosoria, Metaxya, Sphaeropteria, Alsophila, and Nephelea. American Journal of Botany 63: 738-758.

Graham, A. 1976. Studies in neotropical paleobotany. II. The Miocene communities of Veracruz, Mexico. Annals of the Missouri Botanical Garden 63: 787-842.

Graham, A. 1987. Miocene communities and paleoenvironments of southern Costa Rica. American Journal of Botany: 74: 1501-1518.

Graham, A. 1988a. Studies in neotropical paleobotany. VI. The lower Miocene communities of Panama-the Cucaracha Formation. Annals of the Missouri Botanical Garden 75:1467-1479. 
Graham, A. 1988b. Studies in neotropical paleobotany. V. The lower Miocene communities of Panama - the Culebra Formation. Annals of the Missouri Botanical Garden 75: 1440-1466.

Graham, A. 1989. Studies in neotropical paleobotany. VII. The lower Miocene communities of Panama-the La Boca Formation. Annals of the Missouri Botanical Garden 76: 50-66.

Graham, A. 1991a. Studies in neotropical paleobotany. VIII. The Pliocene communities of Panama-introduction and ferns, gymnosperms, angiosperms (monocots). Annals of the Missouri Botanical Garden 78: 190-200.

Graham, A. 1991b. Studies in neotropical paleobotany. IX. The Pliocene communities of Panama-angiosperms (dicots). Annals of the Missouri Botanical Garden 78: 201-223.

Graham, A. 1991c. Studies in neotropical paleobotany. X. The Pliocene communities of Panama-composition, numerical representations, and paleocommunity/paleoenvironmental reconstructions. Annals of the Missouri Botanical Garden 78: 465-475.

Graham, A. 1998. Studies in neotropical paleobotany. XI. Late Tertiary vegetation and environments of southern Guatemala: palynofloras from the Mio-Pliocene Padre Miguel Group and the Pliocene Herrería Formation. American Journal of Botany 85: 1409-1425.

Graham, A. 1999a. Late Cretaceous and Cenozoic history of North American vegetation (north of Mexico). Oxford University Press, New York, New York, USA.

Graham, A. 1999b. Studies in neotropical paleobotany. XIII. An Oligo-Miocene palynoflora from Simojovel (Chiapas, Mexico). American Journal of Botany 86: 17-31.

Graham, A., and D. M. Jarzen. 1969. Studies in neotropical paleobotany. I. The Oligocene communities of Puerto Rico. Annals of the Missouri Botanical Garden 56: 308-357.

Gray, J. (Coordinator). 1965. Techniques in palynology. In B. Kummel and D. Raup [eds.], Handbook of paleontological techniques, 471-706. W. H. Freeman, San Francisco, California, USA.

Gregory-Wodzicki, K. M. 2000. Uplift history of the Central and Northern Andes: a review. Bulletin of the Geological Society of America 112: 1091-1105.

Gregory-Wodzicki, K. M., W. C. McIntosh, and K. Velásquez. 1998. Climatic and tectonic implications of the late Miocene Jakokkota flora, Bolivian Altiplano. Journal of South American Earth Sciences 11: 533-560.

Hay, W. W. 1996. Tectonics and climate. Geologische Rundschau 85: 409-437.

Hays, P. E., N. G. Pisias, and A. K. Roelofs. 1989. Paleoceanography of the eastern equatorial Pacific during the Pliocene: a high resolution radiolarian study. Paleoceanography 4: 57-73.

Isacks, B. L. 1988. Uplift of the Central Andean Plateau and bending of the Bolivian orocline. Journal of Geophysical Research 93: 3211-3231.

Kennan, L. S. H. Lamb, and L. Hoke. 1997. High-altitude palaeosurfaces in the Bolivian Andes: evidence for late Cenozoic surface uplift. In W. Widdowson [ed.], Palaeosurfaces: recognition, reconstruction and palaeoenvironmental interpretation, 307-323. Geological Society of London Special Publication 120. London, UK..

Killeen, T. J., E. García E., and S. G. Beck [eds.]. 1993. Guía de árboles de Bolivia. Herbario Nacional de Bolivia, La Paz, Bolivia and Missouri Botanical Garden, St. Louis, Missouri, USA.

King, T. 1996. Equatorial Pacific sea surface temperatures, faunal patterns, and carbonate burial during the Pliocene. Marine Micropaleontology 27: 63-84.

Lorente, M. A. 1986. Palynology and palynofacies of the upper Tertiary in Venezuela. J. Cramer, Berlin, Germany.

Masek, J. G., B. L. Isacks, T. L. Gubbels, and E. J. Fielding. 1994. Erosion and tectonics at the margins of continental plateaus. Journal of Geophysical Research 99: 13,941-13,956. 
Meyer, H. W. 1992. Lapse rates and other variables applied to estimating paleoaltitudes from fossil floras. Palaeogeography, Palaeoclimatology, Palaeoecology 99: 71-99.

Muñoz, N., and R. Charrier. 1996. Uplift of the western border of the Altiplano on a west-vergent thrust system, northern Chile. Journal of South American Earth Sciences 9: 171-181.

Mosbrugger, V., and T. Utescher. 1997. The coexistence approach-a method for quantitative reconstructions of Tertiary terrestrial palaeoclimate data using plant fossils. Palaeogeography, Palaeoclimatology, Palaeoecology 134: 61-86.

Navarro, G. 1996. Catálogo ecológico preliminary de las Cactáceas de Bolivia. Lazaroa 17: 33-84.

Nee, M. 1999. Flora de la region del Parque Nacional Amboró Borrador. In press, New York Botanical Garden, Bronx, New York.

Parrish, J. T. 1998. Interpreting pre-Quaternary climate from the geologic record. Columbia University Press, New York, NY, USA.

Raymo, M. W., and W. F. Ruddiman. 1992. Tectonic forcing of late Cenozoic climate. Nature 359: 117-122.

Rivera, M. O., S. Libermann, S. Beck, and M. Moraes. 1996. Vegetación de Bolivia. In K. Mihotek [ed.], Comunidades territories indígenas y biodiversidad en Bolivia, pp. 169-222. Centro de Investigación y Manejo de Recursos Naturales Renovables. Santa Cruz, Bolivia.

Roche, M. A. 1993. El clima de Bolivia. In M. A. Roche, J. Bourges, E. Salas, and C. Diaz [eds.], Actas del Seminario PHICAB, pp. 81-93. SENAMHI, IHH, ORSTOM, CONAPHI. La Paz, Bolivia.

Roubik, D. W., and J. E. Moreno P. 1991. Pollen and spores of Barro Colorado Island. Missouri Botanical Garden, St. Louis, Missouri, USA.

Ruddiman, W. F., and J. E. Kutzbach. 1989. Forcing of late Cenozoic northern hemisphere climate by plateau uplift in southern Asia and the American west. Journal of Geophysical Research 94: 18409-18427.

Ruddiman, M. E. Raymo, W. L. Prell, and J. E. Kutzbach. 1997. The uplift-climate connection: a synthesis. In W. F. Ruddiman [ed.], Uplift and climate change, 471-515. Plenum Press, New York, NY.

Tomasini-Ortiz, A., and E. Martínez-Hernández. 1984. Palinología del Eoceno-Oligoceno de Simojovel, Chiapas. Paleontología Mexicana 50: 1-61.

Traverse, A. 1988. Paleopalynology. Unwin Hyman, Boston, Massachusetts, USA.

Tryon, A. F., and B. Lugardon. 1991. Spores of the Pteridophyta. Springer-Verlag, Berlin, Germany.

Tryon, R. M., and A. F. Tryon. 1982. Ferns and allied plants with special reference to tropical America. Springer-Verlag, Berlin, Germany.

Wijninga, V. M. 1996. Paleobotany and palynology of Neogene sediments from the High Plain of Bogotá (Colombia). Ph.D. dissertation, University of Amsterdam, Amsterdam, The Netherlands.

Wolfe, J. A. 1979. Temperature parameters of humid to mesic forests of eastern Asia and relation to forests of other regions of the northern hemisphere and Australia. United States Geological Survey Professional Paper 1106: 1-37.

Wolfe, J. A. 1992. An analysis of present-day lapse rates in the western conterminous United States and their significance to paleoaltitudinal estimates. United States Geological Survey Bulletin 1964: 1-35.

Wolfe, J. A. 1993. A method of obtaining climatic parameters from leaf assemblages. United States Geological Survey Bulletin 2040: 1-71. 
Wolfe, J. A., C. E. Forest, and P. Molnar. 1998. Paleobotanical evidence of Eocene and Oligocene paleoaltitudes in midlatitude western North America. Bulletin of the Geological Society of America 110: 664-678.

Wolfe, J. A., H. E. Schorn, C. E. Forest, and P. Molnar. 1997. Paleobotanical evidence for high altitudes in Nevada during the Miocene. Science 276: 1672-1675. 
Table 1. Composition, numerical representation, and elevational range $(\mathrm{m})$ in Bolivia of the nearest living equivalents of the Pislepampa palynoflora. Percentages are based on counts of 200 of all palynomorphs (first column of figures) and of palynomorphs excluding spores of ferns and allied groups (second column of figures). A dash indicates specimens not encountered in the count of 200.

\begin{tabular}{|c|c|c|c|}
\hline Taxon & $\%$ & $\%$ & Elevation range \\
\hline Isoetes & 1.5 & & \\
\hline Lycopodium type 1 & 1.5 & & \\
\hline Lycopodium type 2 & 0.5 & & \\
\hline Lycopodium type 3 & - & & \\
\hline Cnemidaria & 0.5 & & \\
\hline Cyathea type 1 & 51.6 & & to $\sim 1500$ \\
\hline Cyathea type 2 & 19.0 & & \\
\hline Cyathea type 3 & - & & \\
\hline Grammitis & 0.5 & & \\
\hline Hymenophyllum & 0.5 & & \\
\hline Pteris & 2.5 & & \\
\hline Trilete fern spore type 1 & 2.0 & & \\
\hline Trilete fern spore type 2 & - & & \\
\hline Danaea & 2 & & \\
\hline Monolete fern spore type 1 & 2 & & \\
\hline Monolete fern spore type 2 & 1 & & \\
\hline Monolete fern spore type 3 & 0.5 & & \\
\hline Monolete fern spore type 4 & 0.5 & & \\
\hline Podocarpus/Prumnopitys & 4.0 & 37 & $1700-3400$ \\
\hline Gramineae & 2.5 & 24 & \\
\hline Palmae & - & & \\
\hline Ilex & 1.5 & 10 & $180-4000$ \\
\hline cf. Oreopanax & - & $1100-3600$ & \\
\hline Cavanillesia & 0.5 & $250-850$ & \\
\hline cf. Pereskia & - & $350-2100$ & \\
\hline Compositae type 1 & 2.5 & 10 & \\
\hline Compositae type 2 & 2 & 6 & \\
\hline Compositae type 3 & - & & \\
\hline Ericaceae & 1.0 & 10 & $1200-3650$ \\
\hline Tetrorchidium & - & 2 & $450-1900$ \\
\hline Unknown type 1 & - & 0.5 & \\
\hline Unknown type 2 & - & & \\
\hline Unknown type 3 & - & & \\
\hline
\end{tabular}


Table 2. Age, location, and references to palynofloras cited in the text.

\begin{tabular}{|l|l|l|l|}
\hline Flora & Age & Location & Reference \\
\hline Cucaracha & Early Miocene & Panama & Graham, 1988a \\
\hline Culebra & Early Miocene & Panama & Graham, 1988b \\
\hline Gatun & Mio-Pliocene & Panama & Graham, 1991a,b,c \\
\hline La Boca & Early Miocene & Panama & Graham, 1989 \\
\hline La Quinta & Oligo-Miocene & Mexico & Graham, 1999b \\
\hline Padre Miguel & Mio-Pliocene & Guatemala & Graham, 1998 \\
\hline Paraje Solo & Pliocene & Mexico & Graham, 1976 \\
\hline San Sebastian & Middle Oligocene & Puerto Rico & $\begin{array}{l}\text { Graham and Jarzen, } \\
1969\end{array}$ \\
\hline Uscari & & & Graham, 1987 \\
\hline
\end{tabular}


Table 3. Paleoclimate and paleoelevation estimates for fossil floras from the Central Andes. Numbers (first column) denote the location of the floras on Fig $1 \mathrm{~b}$.

\begin{tabular}{|c|c|c|c|c|c|c|c|}
\hline Flora & Age(MA) & Method & $\operatorname{MAT}\left({ }^{\circ} \mathrm{C}\right)$ & MAP(mm) & PaleoE(m) & $\operatorname{ModE}(\mathrm{m})$ & Ref \\
\hline 1 Chucal & $25-19$ & A & - & - & $1000 \pm 1500$ & 4200 & $1,2,3$ \\
\hline 2 Potosí & $20.8-13.8$ & $\mathrm{P}$ & $21.6 \pm 2.1$ & $500 \pm 400$ & $\begin{array}{l}0-1320 \\
\pm 1200\end{array}$ & 4300 & 3,4 \\
\hline 3 Jakokkota & $10.66 \pm 0.6$ & $\mathrm{P}$ & $\begin{array}{l}18.6-20.0 \\
\pm 2.5\end{array}$ & $500 \pm 400$ & $\begin{array}{l}590-1610 \pm \\
1200\end{array}$ & 3940 & 3,5 \\
\hline 4. Pislepampa & $7-6$ & $\mathrm{~A}, \mathrm{P}$ & 220 & $1000-1500$ & $1200-1400$ & 3600 & 6,7 \\
\hline
\end{tabular}

Note: 1 . Method = method used to estimate paleoclimate and paleoelevation, $A=$ modern analog, $\mathrm{P}=$ foliar physiognomy. MAT $=$ mean annual temperature. $\mathrm{MAP}=$ mean annual precipitation. PaleoE $=$ paleoelevation. ModE $=$ modern elevation. Refs $=$ References, $1=$ Charrier, Muñoz, and Palma-Heldt (1994), 2 = Muñoz and Charrier (1996), 3 = GregoryWodzicki, McIntosh, and Velásquez (1998), 4 = Berry (1939), 5 = Berry (1922b), 6 = Berry (1922a), 7 = this study.

Table 4. Percentage surface uplift represented by sites in the Central Andes. Data are from this study and from Gregory-Wodzicki (2000). For Province, $\mathrm{A}=$ Altiplano, EC = Eastern Cordillera. Uplift $=$ percentage of total uplift (rock uplift-isotatic rebound) represented by the paleoelevation of the site.

\begin{tabular}{|l|l|l|l|l|}
\hline Indicator & Province & Age (Ma) & Isostatic rebound & Uplift (\%) \\
\hline Marine Sediments & A & $73-60$ & $\sim 0$ & 0 \\
\hline Crustal Shortening & A,EC & $\sim 25$ & $\sim 0$ & 30 \\
\hline Chucal & A & $25-19$ & $\sim 0$ & 24 \\
\hline Potosí & EC & $20.8-13.8$ & $200-1200$ & $0-43$ \\
\hline Jakokkota & A & $10.66 \pm 0.6$ & $\sim 0$ & $15-41$ \\
\hline Erosion Surfaces & EC & 10 & $200-1200$ & $30-65$ \\
\hline Pislepampa & EC & $7-6$ & $200-1200$ & $35-58$ \\
\hline
\end{tabular}




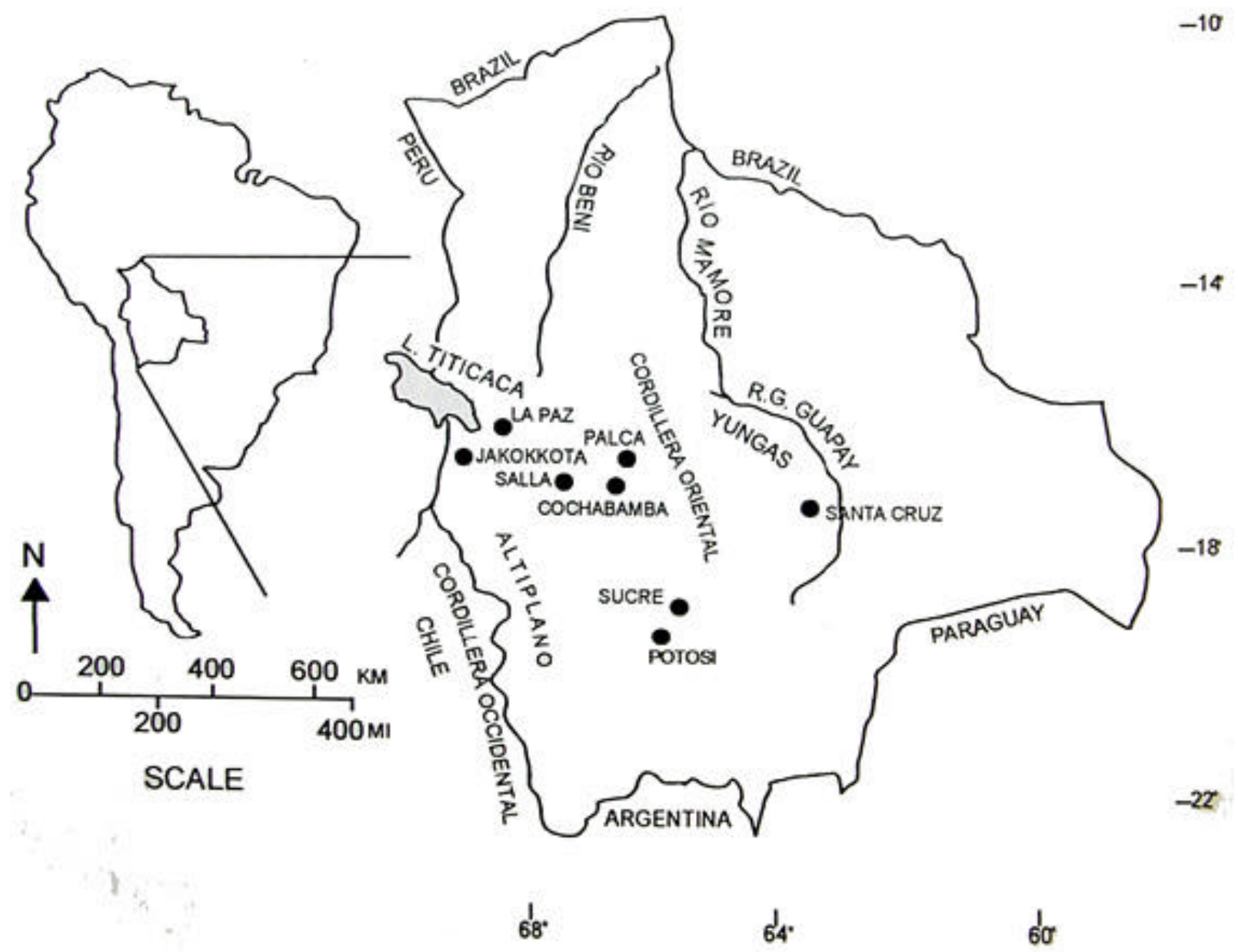

Fig. 1. (a). Index of place names mentioned in the text. 


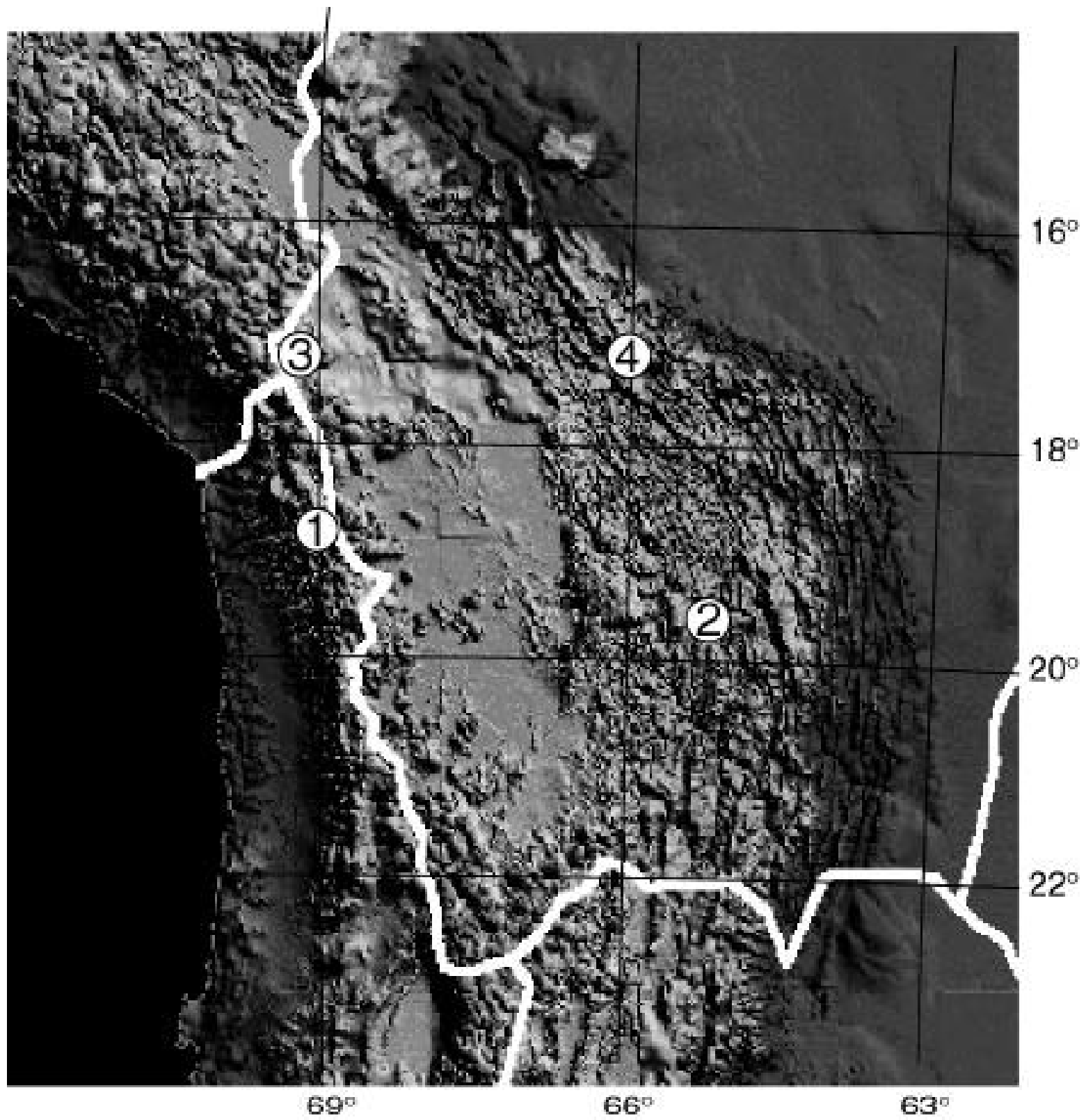

(b). Relief map of the Central Andes (United States Geological Survey 30 acr-second DEM

(digital elevation model) data as processed by the Cornell Andes Project) showing the location of the four floras discussed in the text. 1. Chucal. 2. Potosí. 3. Jakokkota. 4. Pislepampa. 


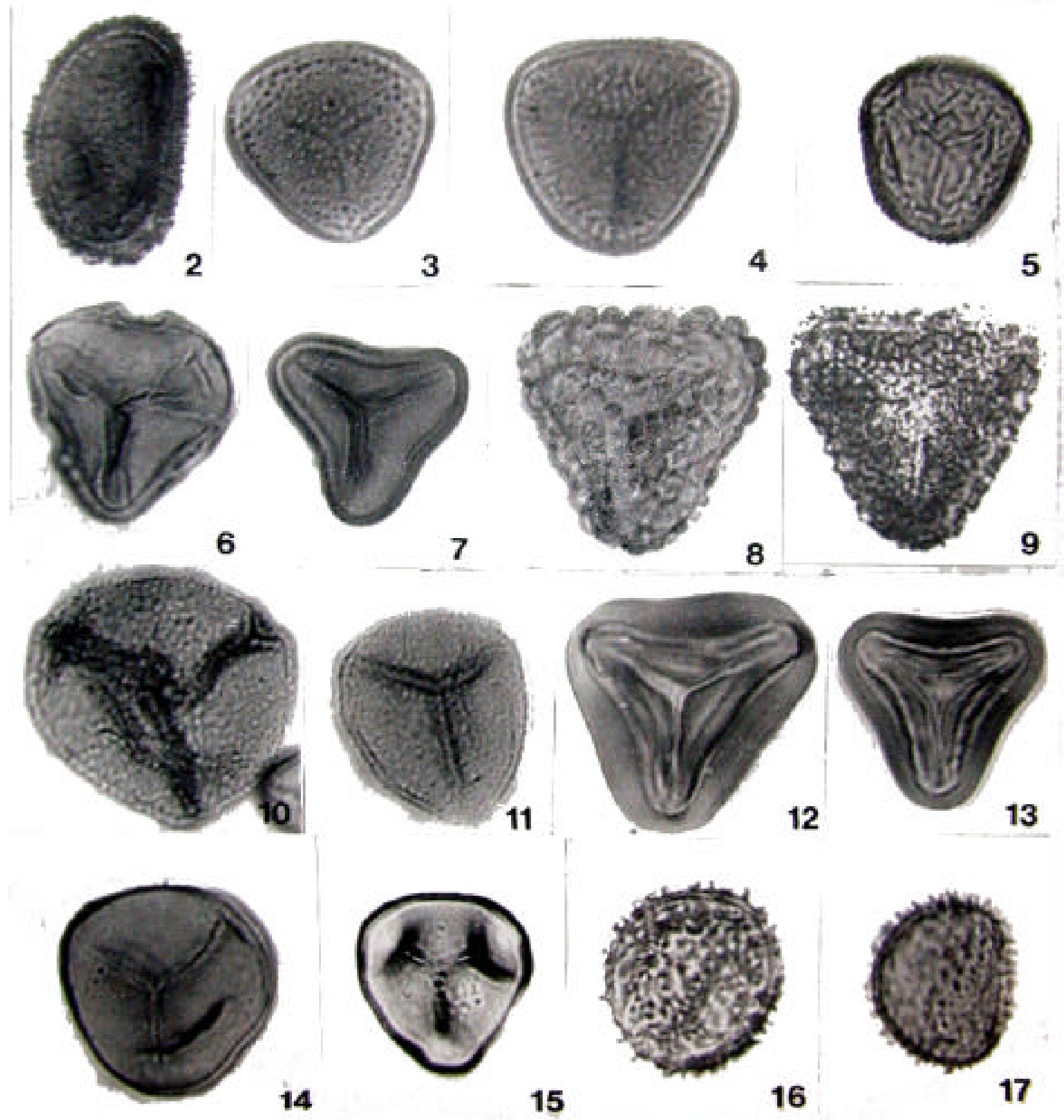

Figs. 2-17. Fossil spores from the Mio-Pliocene Pislepampa flora, Bolivia. See text for descriptions and measurements, and Table 1 for numerical representations. 2. Isoetes. 3. Lycopodium type 1. 4. Lycopodium type 2. 5. Lycopodium type 3. 6. Cnemidaria. 7. Cyathea type 1. 8. Cyathea type 2. 9. Cyathea type 3. 10. Grammitis. 11. Hymenophyllum. 12, 13. Pteris. 14. Trilete fern spore type 1. 15. Trilete fern spore type 2. 16, 17. Danaea. 


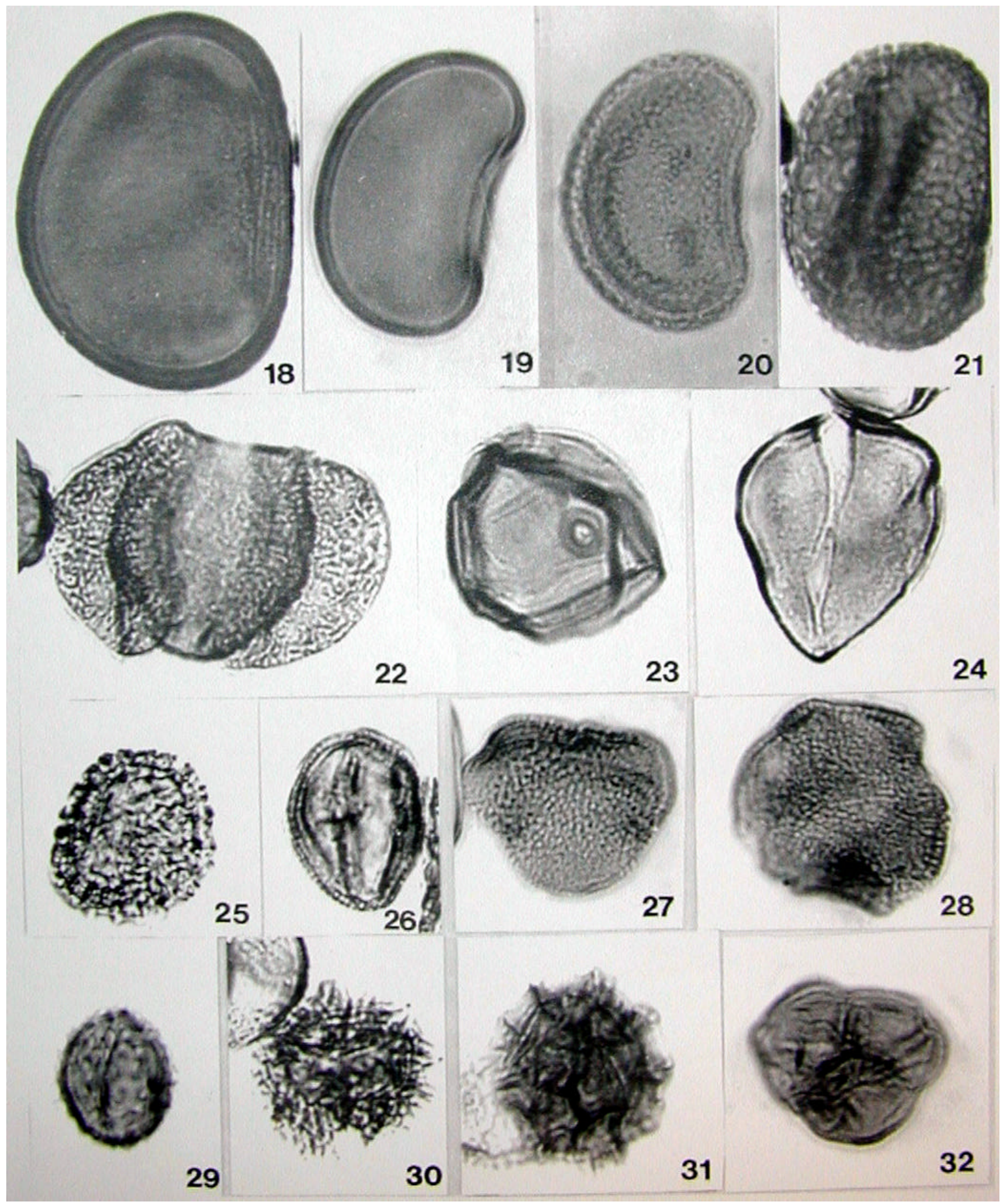

Figs. 18-32. Fossil spores and pollen from the Mio-Pliocene Pislepampa flora, Bolivia. See text for descriptions and measurements, and Table 1 for numerical representations. 18. Monolete fern spore type 1. 19. Monolete fern spore type 2. 20. Monolete fern spore type 3. 21. Monolete fern spore type 4. 22. Podocarpus (Prumnopitys). 23. Gramineae. 24. Palmae. 25. Ilex. 26. cf. Oreopanax. 27. Cavanillesia. 28. cf. Pereskia. 29. Compositae type 1. 30. Compositae type 2. 31. cf. Compositae (Vernonieae). 32. Ericaceae. 


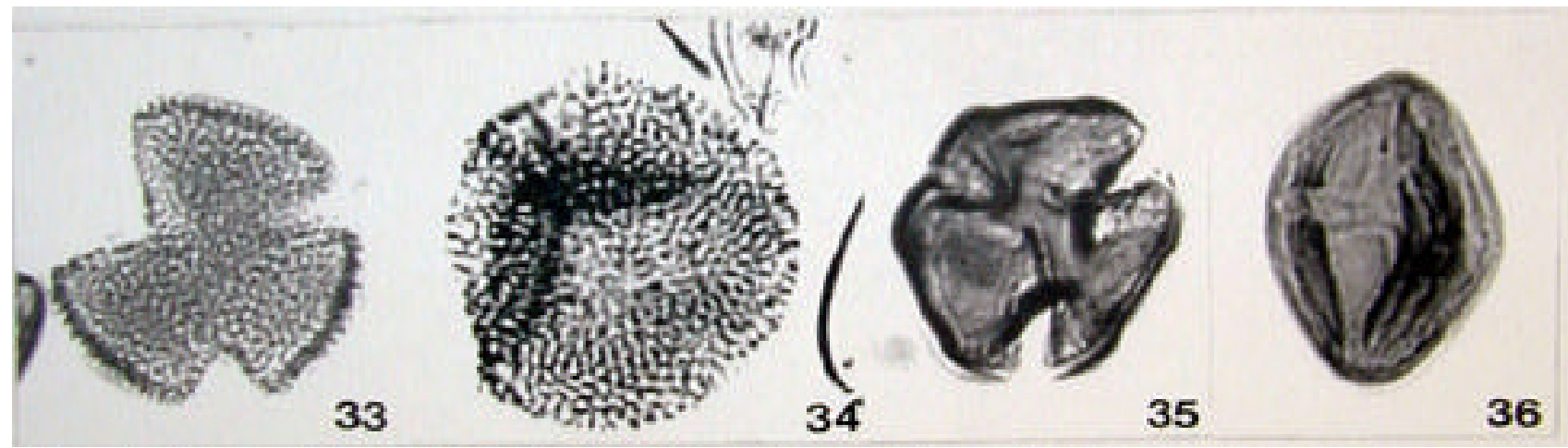

Figs. 33-36. Fossil pollen from the Mio-Pliocene Pislepampa flora, Bolivia. See text for descriptions and measurements, and Table 1 for numerical representations. 33. Tetrorchidium. 34. Unknown type 1. 35. Unknown type 2. 36. Unknown type 3.

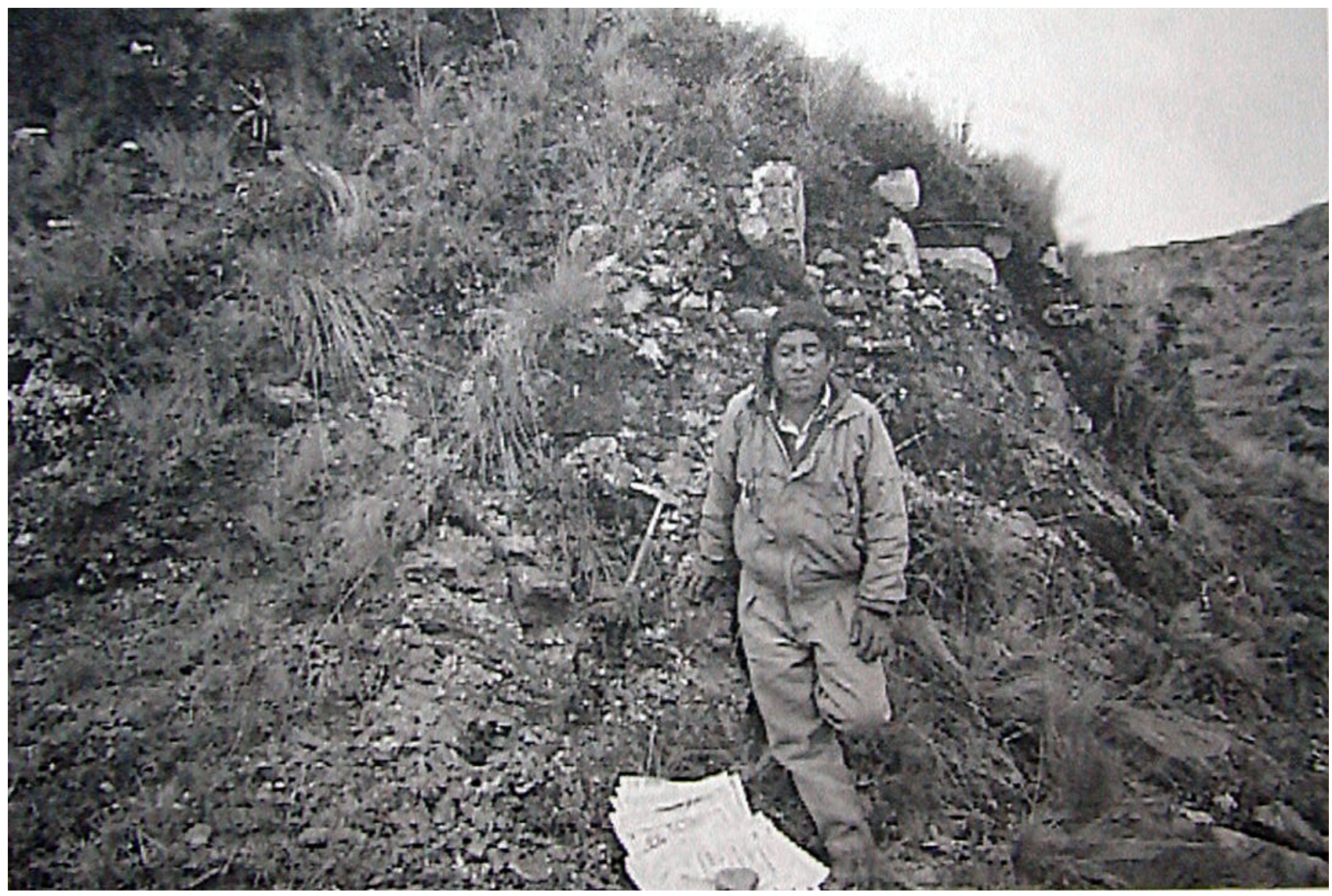

Fig. 37. The plant fossil locality at Pislepampa with field assistant Luis Huanca. 


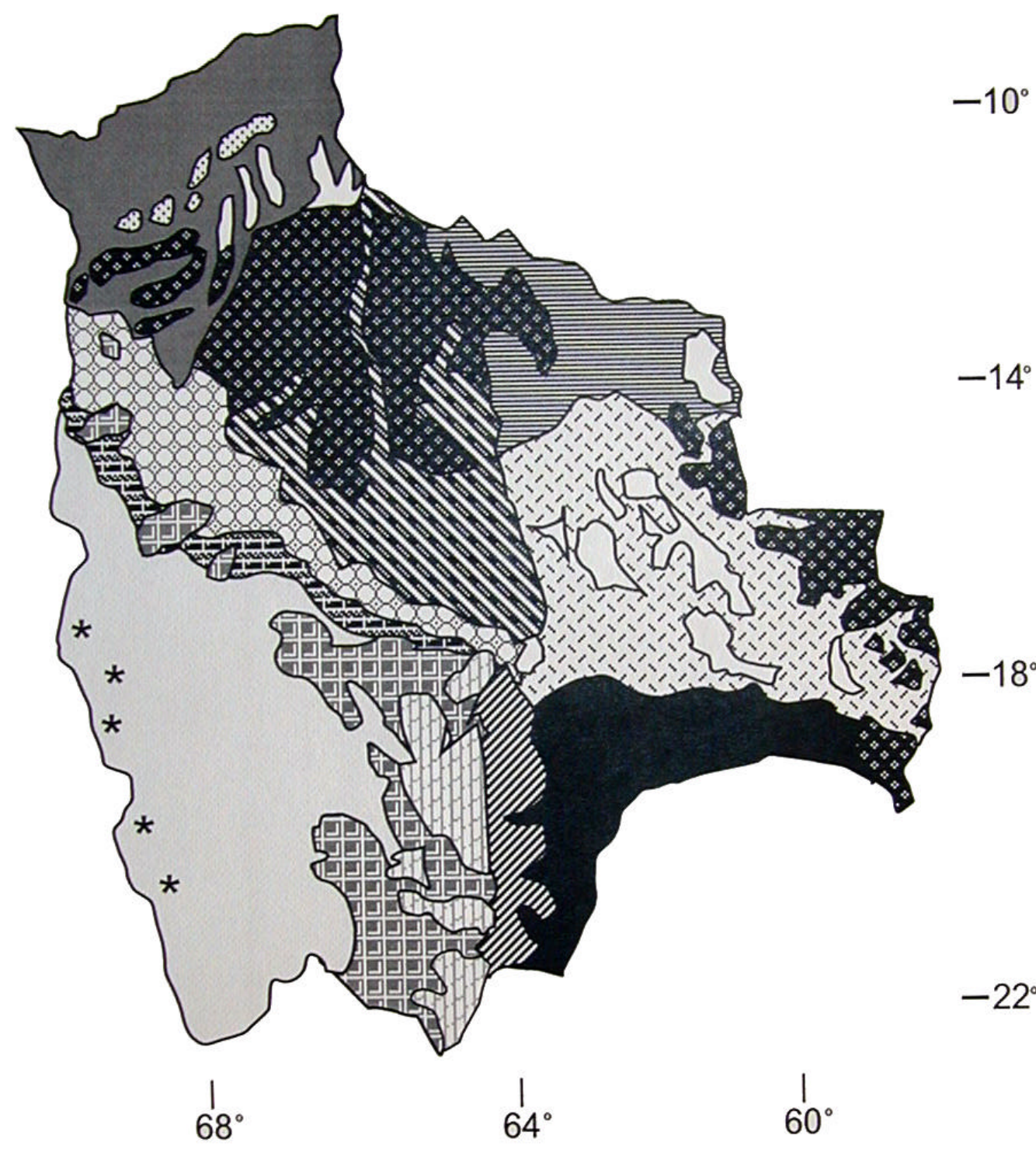

Bosque Amazónico

שMA Bosque Serrano Chaqueño

Bosque Húmedo de Llanura

$\because$ Sabanas Humedas

高Bosque Húmedo del Escudo Precámbrico Bosque Montano Húmedo

B., Bosque Semideciduo Chiquitano

Ceja de Monte Yungueña

Campos Cerrados

매] Bosque Tucumano-Boliviano

Campos Amazónicos

[ب] Valles Secos Interandinos

Bosque Seco Chaqueño

Puna y Vegetación Altoandina

* Bosquecillos de Polylepis

Fig. 38. Vegetation map of Bolivia (based on Killeen, García E., and Beck, 1993). 


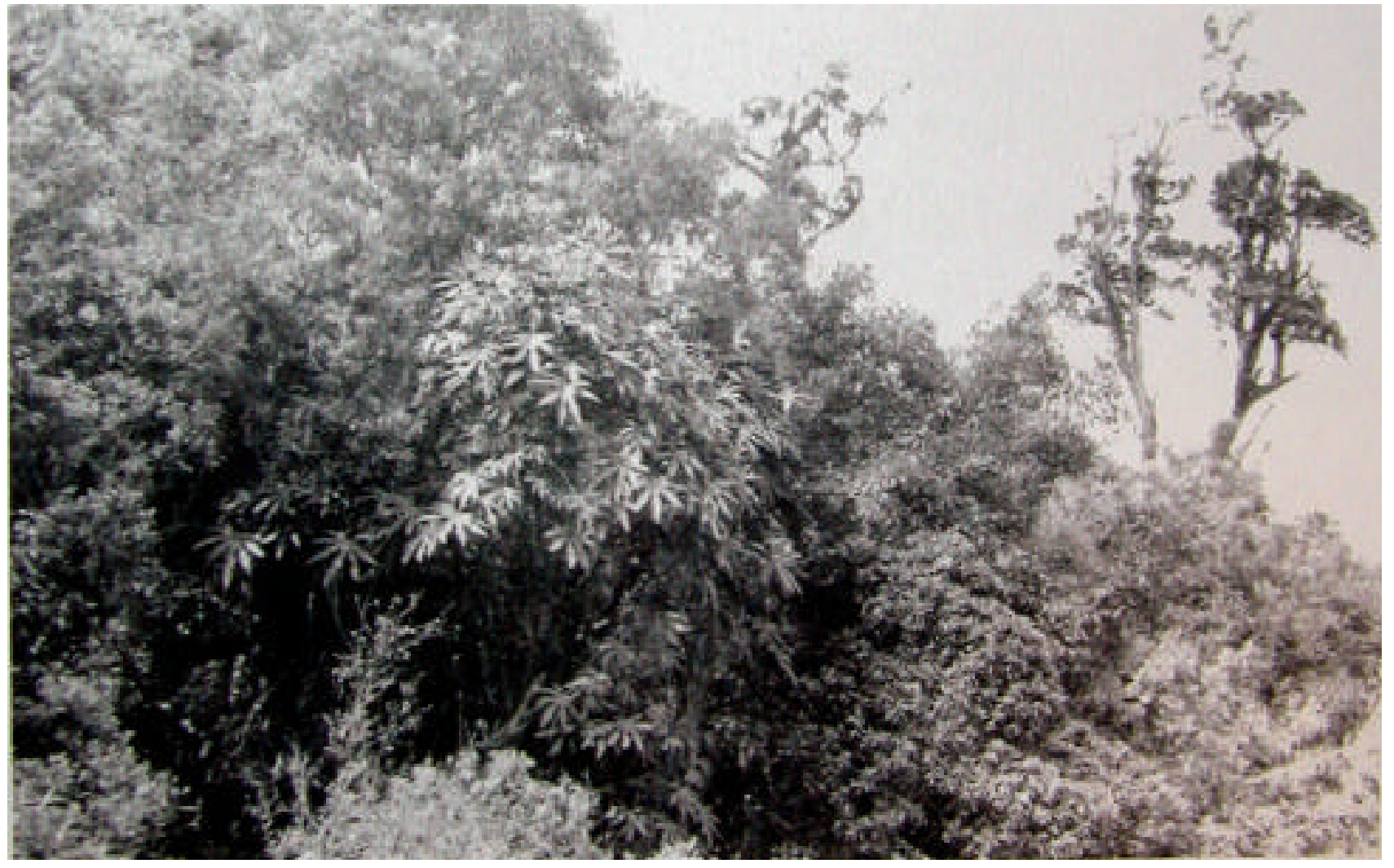

Fig. 39. Cloud forest vegetation near Comarapa, Bolivia. Note the presence of

Oreopanax (palmate-leaved plant in the center of the photograph) and Podocarpus (Prumnopitys; tree projecting above the low canopy to the right). Pollen of both are present in the Mio-Pliocene Pislepampa flora. 


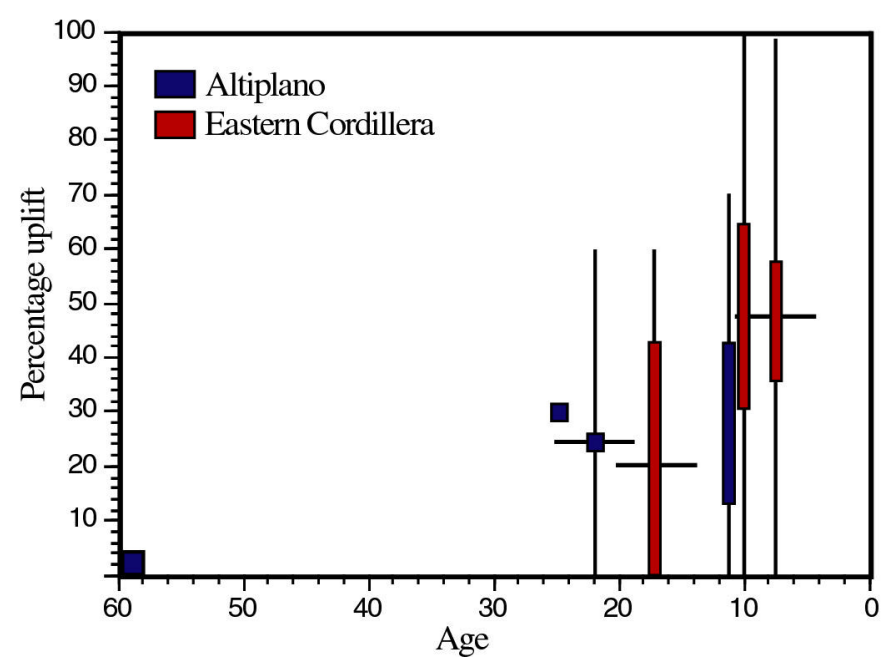

Fig. 40. Paleoelevation estimates for the Central Andes. Data listed in Table 4. 